\title{
Redesign Educational spaces identity and existing city relationship
}

\author{
Anna Celeste Rubino ${ }^{1}$
}

\begin{abstract}
The task of this paper is to describe the relationship between the architectural buildings plan, addressed to educational spaces, and the context where the same ones are located. Specific attention is made to the analysis of relationship of continuity established between the inner and outer space. The intention is to go through some examples of architectures where the students are the final users, realized in the Centre and North of Italy during the second half of 20th Century, which might be internationally less well known but appear not less interesting. The goal is to investigate the willing of their creators in innovating the Italian architectural language, called to measure itself with the Modern European Architecture experimentations, but that doesn't interrupt the connections with the history and the identity of its own places.

In defining the relationship that the spaces of architecture establish with the territory and their power of social renewal, educational structures play a key role as a place of exchange and connection with the neighbourhood and with the city where school life and the life of society are called and interfaced with a sharing process that contributes to the conscious development of individuals.
\end{abstract}

Keywords: Architecture, educational structures, development

\section{Introduction}

The architecture has always represented a strong element in the definition of a city and a national identity. In the present Italian panorama, characterized by a political inconsistency and by a lack of movements inspired by strong ideals in which people can fully identify itself, it would be suitable return to the architecture the main character role in the definition of the features of its own local and national identity, within the European cultural panorama.

In the research of its authenticity, the architecture cannot be considered truly substantial if its designer is not settled in his own culture.

By the architects' studies, like Van Eyck, Bakema, The Smithson, Candilis, Woods, comes out a planning methodology, based on a different visual order with respect to the geometrical and the big volumes one of Modern Movement.

A representative project of designing spaces for education, in the context of 20th century architecture in Italy, is given to us by the De Carlo's experience at Urbino since, according to Blundell Jones's definition, he represents a "builder architect" open to methodological impulses of international breath, that interacts with the local constructive tradition, as well as an educator in foreground that makes of architectural research a complex moment, where the users requests are the starting point for a human-scale architectural elaboration (Blundell Jones, 2004, p.61). 
De Carlo's contribution, on the issues relevant to the city and the definition of its identity in relation with the territory and the landscape, is dated back to 50's, when a decisive change in the urban layout starts, and architects are involved to give a new "face" at the urban centres destroyed by the war.

\section{Methodology}

The research is based on multi-method interpretative study involving observation of architectures and comparative analysis, based on functionality criteria, relationship with the urban context and search for architectural quality in the distribution of spaces and in the compositional language of the facades.

Many data and information have been collected from participation in events related to school building and 20th century architecture.

The buildings described were visited and a research was carried out by consulting the updated literature on the architects mentioned and on the role that these architectures play in the narration of the history of contemporary architecture in the international sphere. Issues regarding the connection between city identity and architecture were the subject of study and comparison during the participation in two international conferences, one called "Architecture and Identity" at Jesus College in Cambridge and the other called "Urban Futures 3" at the University of Glouchestershire.

The study of the architectures in urban and territorial scale described, located in the Marche region, has been the subject of comparison with professionals and architectural professors operating in the area.

They have also been deepened in specific conferences, such as RESET (Energy Redevelopment Sustainability in buildings and in the Territory of Urbino), an event in which the theme of urban regeneration and building reconstruction is studied.

Regarding the aspects related to the design of school spaces and their use, information were gathered during events organized within the Università Politecnica delle Marche in Ancona, in the presence of designers and scholars of learning spaces, such as a conference and exhibition entitled "The architecture of the school".

Reports and national and international documents relating to school construction and renovation programs were analyzed.

\section{Discussion}

\subsection{The interventions on the Urbino city by De Carlo}

In 1959, during a congress organized by the Planning National Institute focused on the "City Aspect", architects like Ludovico Quaroni, Giancarlo De Carlo, Eduardo Vittoria and Piero Moroni illustrate the idea of a City speaking to the territory. A concept of "open City" or "City-Region" which spreads out, considering the pre-existing, and puts the basis for new principles relevant to planning management of this new City model.

The designer cannot disregard the relationship between architecture and planning and the need to consider their connection with disciplines like sociology, economy and politics. 
In 1962, at Stresa, De Carlo held an international congress organized by the economical and social studies branch of Lombardo Institute. In such occasion the contemporary city developments were analysed, and the premises for a kind of planning design, having as reference point the relationship between the urban centre and the territory, were put.

In the same congress, the issue of un-controlled expansion of the urban pattern generated by the economical growth of 50's and the subsequent loss of role of historical centre, as place of civil conscience and propulsive centre of the main activity of a city, have been analysed.

As stated by Tafuri, the Stresa congress about the City-Region ratifies the "end of the "model", of the global shape to be imposed to the urban dynamic", in which De Carlo defines the concept of City-Region as an assembly of dynamic relationships established inside a territorial galaxy of specialized settlements made homogeneous by the same interrelationships (Tafuri, 1986, p.98).

De Carlo's serious involvement into the national urban discussion is associated to his designer and planner activity. In De Carlo's vision the architectural product has to be thought in the biggest design of the city, as such as witnessed by his experience started in the Italy centre in 1958, when the Architect receives his first task as planner for the General Regulator Plan of Urbino.

De Carlo's work focused on Urbino city, characterizes most of his professional career and brings the architect not only to consider the regional characters of architecture and the surrounding landscape, but make him busy in a territorial reading urban and social as well, in all his aspects, essential to opportunely address the future planning choices.

In the complex and polyhedral intervention on the Urbino city, De Carlo makes merge that baggage of experiences, which goes through the strong link with the early Modern Movement, in comparison with the tradition of the Organicist Architecture, the rejection of academic formalism of the International Style and so down to the development of the concept of participation as a way to enable architecture to face the social reality that forms its context (Zucchi, 1992).

De Carlo is called to intervene on a city boasting a glorious Renaissance past, where the complexity and beauty of the Duke of Montefeltro's architectural program are witnessed by the wonderful example of town-palace, designed in the second half of the 15th Century by architects of calibre as Luciano Laurana and Francesco di Giorgio Martini.

In the several interventions implemented in Urbino, De Carlo was able to preserve in its secular identity the precious Renaissance nucleus by developing a plan based on a wise topographic study, in which the project unfolds between the conservation of the historical nucleus, with reuse interventions of some buildings and the design of new parts of the city.

The Colleges design of Urbino follows some of the historical buildings restorations, that in the past had hosted the functions of the ancient residence of the Duke and monasteries, artefacts with courtyards and closed spaces, which the architect valorises and safeguards by designing a sequence of functional spaces for university teaching, offices and common environments.

This intervention method, respectful of the identity of the historical city, conveys internationally De Carlo's projects among the best experiences of perfect integration between pre-existing and new buildings within a building. 
In this way, Faculty of Law, between 1966 and 1968, Faculty of Educational Sciences, between 1968 and 1976, and the Faculty of Economics between 1989 and 2000 were incorporated into the historical pattern of the city.

The high number of students that these new university entities would have attracted to Urbino demanded the realization of large complexes for student residences, also entrusted to De Carlo.

In the design of Urbino colleges emerges the vision of a "ductile approach to form", matured by the architect during the experience of Team X, from 1959 to 1981 (Tafuri, 1986, p.149).

Sharing ideas with colleagues such as Smithson, Shadrach Woods, Ralph Erskine, Jacob Bakema, and interest in Aldo van Eyck's studies of anthropology are part of De Carlo's projects for the Urbino colleges.

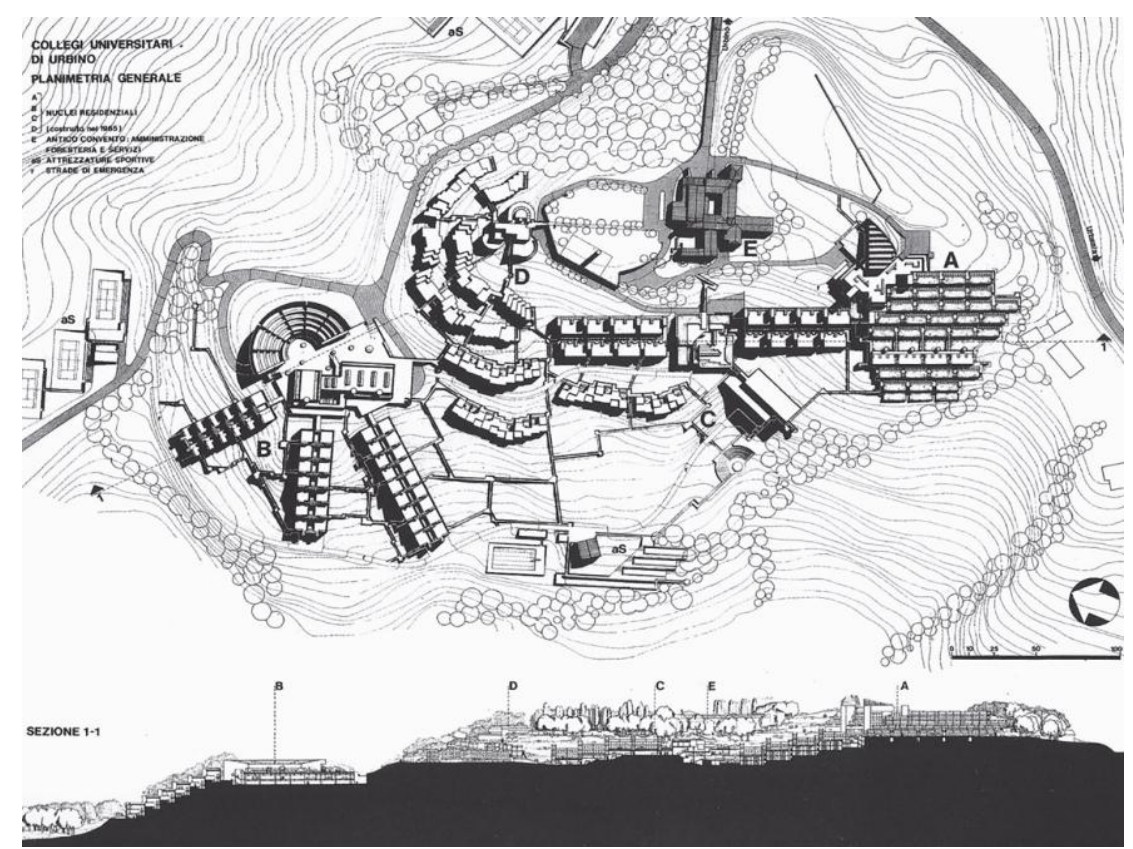

fig. 1 Plan of the Urbino University Colleges designed by Giancarlo De Carlo

Particularly in the College of Colle project, built between 1962 and 1966, De Carlo's intention was to elaborate "a spontaneous architecture" also borrowed from the sharing of van Eyck's idea of developing a "place form "consonant with the needs of the city that was emerging in the Second half of the $20^{\text {th }}$ Century. The Dutch architect has a critical attitude towards the functional city plan that was developing in the Netherlands after the war and imagines architectures able to answer to the unchanged needs of the individual as large citadels articulated on the basis of concepts such as reciprocity and duplicity, where the complementary qualities - small and large, light and shadow, private and public, open-closed, home-town - contribute to create a composite balance between the parties (Plummer, 2016, p.152).

In the Van Eyck project for Amsterdam's orphanage, duality is readable in the wise alternation of inner and outer spaces, where the "threshold" is no longer a rigid 
boundary element but amplifies to favour the idea of space continuity. Starting by the studies of the German philosopher Martin Buber, van Eyck elaborates the concept of inbetween that, within the community, activates interaction mechanisms necessary for the dialogue between members.

In the light of these ideas in the post-war period, architecture has formulated strategies about the relationship between social relations and the environment and asked how the architectural project could affect social relationships. The 1962 Smithsonian concept of cluster, network, grid and pathway concepts and their ability to influence the relationship system is the basis of many projects by Team $\mathrm{X}$ architects, of which De Carlo is one of the most active (Riboldi \& Torricelli, 2016).

In line with Van Eyck's ideals, De Carlo's projects do not claim to impose a spatial order on the city or to modify the habits of people living in those specific places, but they start from a concept of the universality of architecture that is being built as it establishes a connection to history and loci genius.
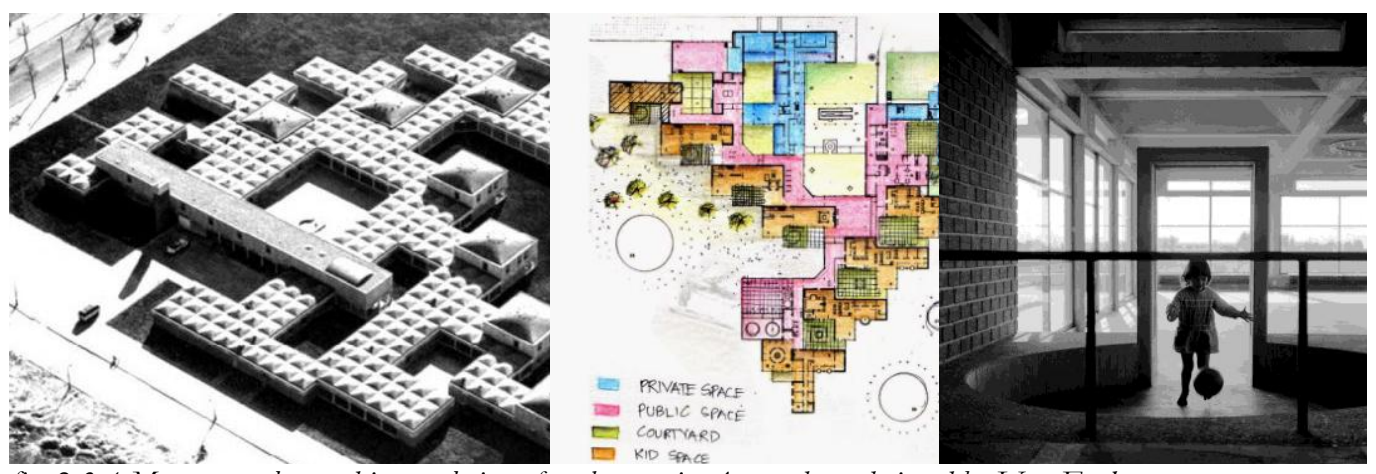

fig. 2-3-4 Maquette, plan and internal view of orphanage in Amsterdam, designed by V an Eyck.

About the Colleges of Urbino de Carlo, Aldo van Eyck writes "Urbino and Francesco di Giorgio together reveal, as the students houses De Carlo built 400 years later, that unity and diversity are ambivalent; that one can only be obtained through the other and that both are essential if what is constructed must be congenial to the people as it really is (Van Eyck, 1966)."

College of Colle, the best known of the residential complexes of Urbino, is located to the southwest of the city on a plateau called Colle of Cappuccini, near an ancient monastery. The college develops on the western side of the hill and has the main entrance to the highest part, while the rooms grow downwards, following the ground level curves to form two long rows of curvilinear curves. The collective spaces volume extends over three levels and is joined down to the series of rooms, linked by stairs and pedestrian paths.

The corridors are not designed as simple steps but as aggregation sites, expanded to the normal dimensions, thought as roads, with rest spaces and points to admire the landscape. The permeability of these bodies is due to the alternation between covered and uncovered areas, the melting of natural light and the artificial light of the interior, where the common spaces become almost squares.

The exposed concrete structure and the red brick tombstones (made by clay excavated on site) recall the language of the New Brutalism celebrated by Bahnam. The central 
building of collective services is characterized by shaded and rounded shapes, arranged around an illuminated space from above.

The student rooms, facing the landscape, are made up of 150 cells lined up on two floors, arranged in a staggered position and grouped together in rows that harmoniously follow the orography of the ground.

In contrast to the idea of rationalist planning supported by CIAM, College of Colle recalls the urban layout typical of some Italian cities, where the houses are placed according to an apparent randomness on the hill sides.

De Carlo imagines the College as a small autonomous community, with its own life but at the same time in dialectical relationship with the nearby Urbino.

The need to build more student residences led the architect to design three more colleges: the College of Vela, the College of Tridente and the College of the Aquilone.

The common elements between these Colleges and College of Colle can be found in the use of concrete and red bricks in sight and in the distribution system characterized by large volumes that house collective spaces separate from the ranks of the rooms. The element that stands out from the Colle complex is in the aggregate scheme of residential units, which are no longer single but aggregated into groups of several rooms.

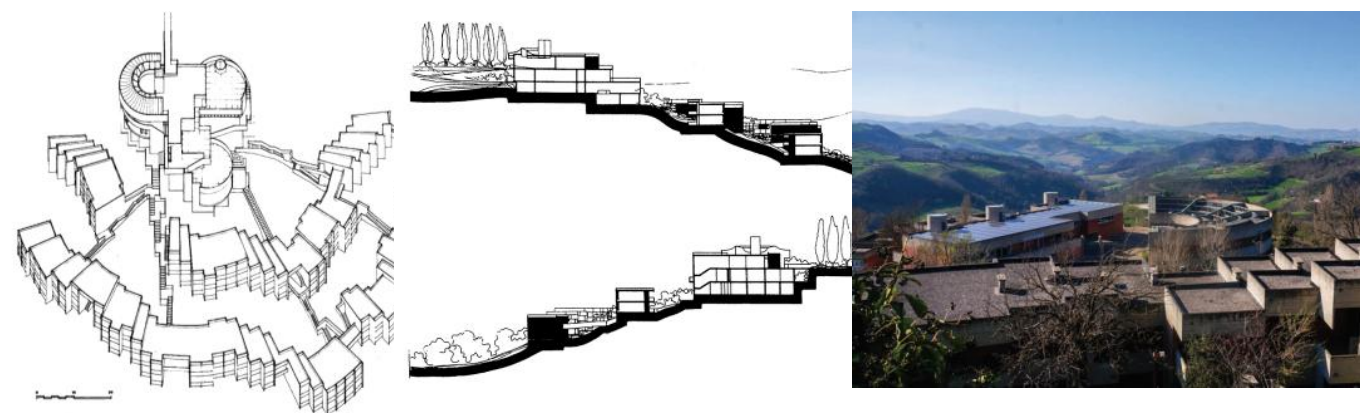

fig. 5-6-7 Collegio del Colle at Urbino. Axonometry, sections and view

In Trident, made between 1973 and 1981, the rooms are on two floors along three steps. Roofs are walk-able by students, such as terraces overlooking the valley, thus reinforcing the sense of mutual penetration between enclosed space and open space already perceptible within the 352 rooms, characterized by large and wide-width windows. The longitudinal volumes, containing the rooms, start from a central nucleus that includes an amphitheater with classrooms, a body with reading rooms, administrative offices, an environment designed for theatrical representations and open spaces to the community. 


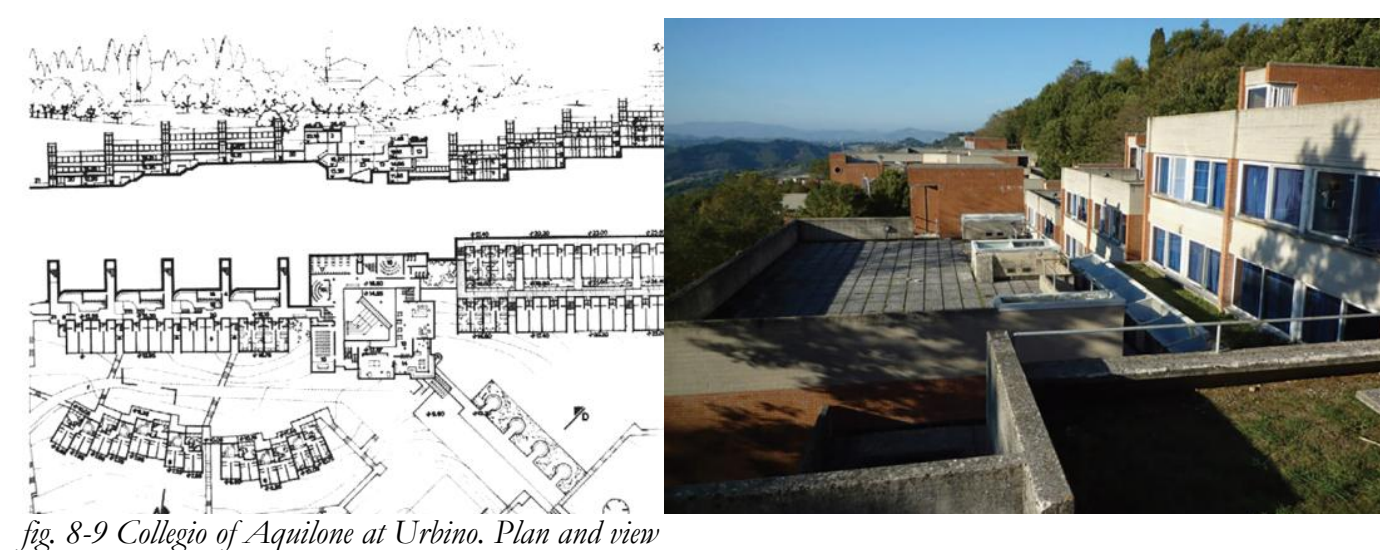

The same system of aggregated modular cells is replicated in the College of Aquilone and in the College of Vela, built between 1973 and 1981. In the latter one, the layout of the factory build changes: in the case of the College of Aquilone some rooms are arranged according to the level curves, once again with a distinct angle, such that each dwelling frames a different stretch of territory and allows to enjoy an unique view. While the two long builds between the College of Colle and College of Vela are made up of cells of four rooms arranged on both sides of a central path. In the case of College of Vela, single and double room groups are more compact and have parallel sloping bands along the side, articulated along orthogonal paths. The space connection with the site is established here by the variation in the floor space dimension of the room groups and the openings along the ceiling of the central corridor.

The relationship between the colleges and the morphology of the city of Urbino is based on a dialectical correlation among the functionality of the structures, the needs of the students and the desire to integrate and enhance each other the built and the surrounding nature.

The legacy of Team X members, and in particular Van Eyck in the design of school buildings planning, is inherited by architect Herman Hertzberger, who is carrying out experiments on "pedagogy of space", especially in Holland.

De Carlo's projects of the Colleges in Urbino and the montessorian schools of Hertzberger in Delft (1966) and in Amsterdam (1980) effectively declare the same themes: the ones of the path as a decisive element of the building and place of socialization, the ones of overcoming dualism between closed space (housing or classroom) and open space (roads, garden, city) and the interplay of them.

\section{The educational architecture in Italy in the late twentieth century}

Compared with the Northern European countries, school building in Italy in the $2^{\text {th }}$ Century was affected by the consequences of war destruction, although from the 1950s, it was attempted to plan systematic interventions throughout the territory.

Already in 1947, architect Ernesto Nathan Rogers had expressed the view that 'educational architecture' (Rogers, 1947) was needed to solve the problems of education, a thesis largely denied in the immediate operational phase. 
The rebuilding plan for schools in Italy was divided into two phases: the first, from 1945 to 1947 , where pre-existing school buildings were repaired and refurbished; the second, begun around 1948, saw the construction of new schools throughout Italy.

In many cases, the newly built schools did not respond adequately to the teaching requirements of the innovative pedagogical theories of Dewey, Montessori and Pizzigoni. Most of the buildings were built with prefabrication techniques, which gave the schools a monotonous and conventional look.

It is since 1960s that the theme of the design of educational spaces is dealt with the aim of a real renewal. The common goal of architects, psychologists and educators was to rethink school spaces to provide concrete answers to the needs of cutting-edge pedagogy.

In Italy, an International Congress of School Building was organized at the XII Triennale in Milan (1960), dedicated to the theme "The House and The School", and in 1963, during a Building Study Congress, the school inspector Luigi Romanini emphasized the attention on pedagogical requirements in the construction of schools.

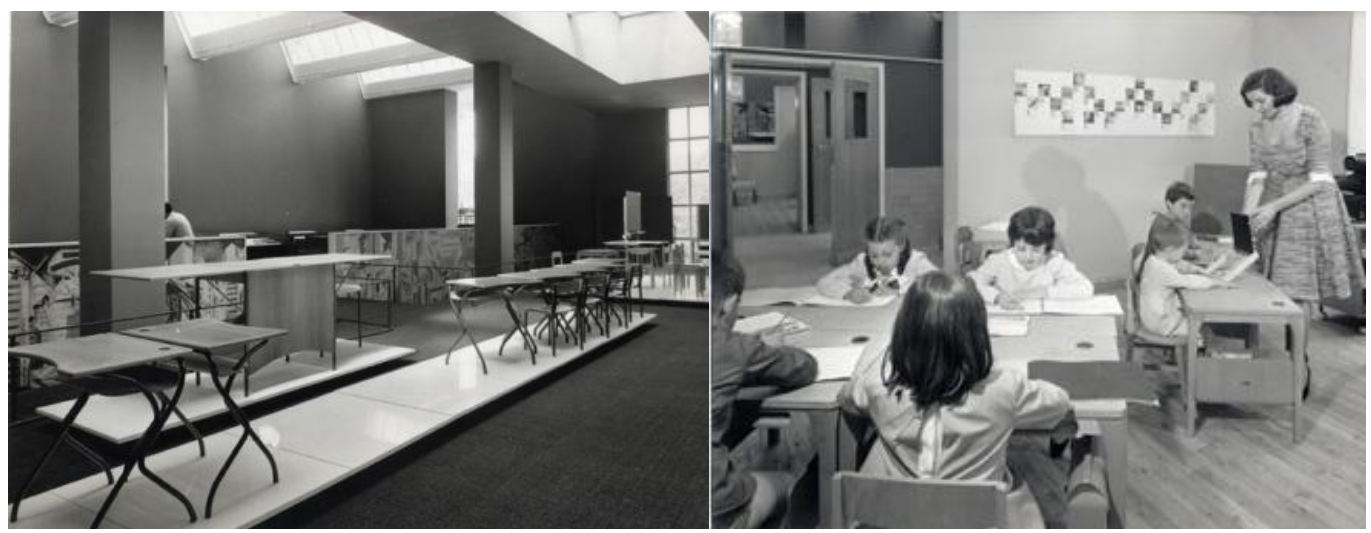

fig. 10-11 Furnishings and photographs exbibited at the XII Triennale in Milan

For some architects, apparently geographically and culturally distant, the ' 60 s represent a favourable moment given by the opening of a modern commitment and economic wellness. It is associated to this the contribution given to Italian architecture in reformulating its language by the so-called masters of the cultured profession: emblematic are the works of Gardella, Albini, Figini and Pollini, Mangiarotti and Viganò, just to name a few.

\section{De Feo's project of scholastic architecture: research of design innovation and relationship with the context}

In this scenario, an architect who stands out for his original and innovative solutions in the field of school building is Vittorio De Feo, whose architectural production merge the Soviet architecture of constructivism relevant to the period from 1917 to 1936, and US architecture in all its facets, from the creative clarity and prosperity of Louis Kahn to "complexities and contradictions" of Robert Venturi.

In some De Feo's architectures is evident the Venturi's lesson on the possibility to be free by the modernist precept that required the unity between the interior and the 
exterior of the building. The De Feo's role assumes an atypical position in the panorama of contemporary Italian architecture history, as it is outlined on one side by the influences of the Roman environment, of which the Ridolfi lesson is recognizable, on the other side by the influences of the English and US English language, readable in the volumetric breakdown of its buildings. In two school complexes he built in central Italy, in the town of Terni, "De Feo does not express as much a poetry (...), he does not want to elaborate typologically suggestive architectures (...) but on the opposite, architectures increasingly dropped in the occasional relationship with the context and the place"(De Feo, 1976).

The influence of Kahn's language is evident in the project drawn up by De Feo, in collaboration with Enrico Ascione, for the special psycho-educational school built for the Province of Terni in 1967.

In this school structure, the architecture wants to contribute to the implementation of innovative didactics, inspired by experimental psycho-didactic methods. The structure is distributed in space by developing replicated volumes that give a sense of continuity to the building, with multifunctional and versatile environments arranged in an alternation of closed and open spaces.

The large complex seen from the above is distributed according to a rectangular perimeter, but the compactness of the form in map is opposed to the volumetric articulation of the elements: a succession of parallelepiped towers that contain the services alternate with the lower volumes containing the classrooms. The seriality of the building is interrupted with discretion, at one end of the building, from the large space that houses a lounge, once covered by a cruise.

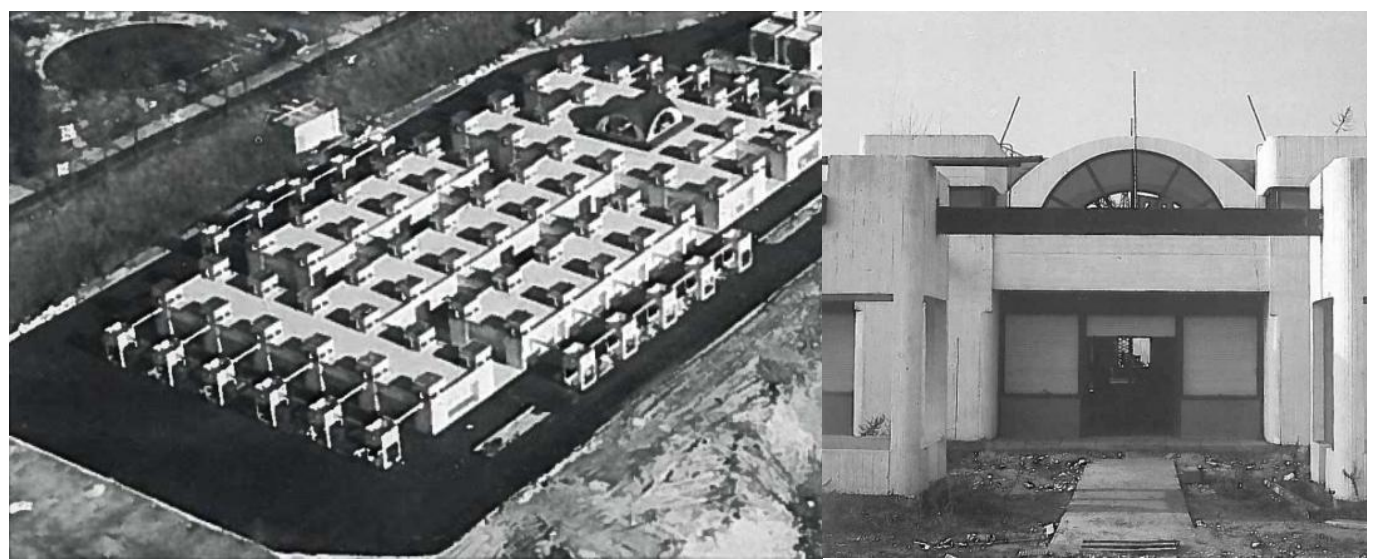

fig. 12-13 Views of Psycho-educational School in Terni

Definitely more inventive and in line with the research that De Feo had already undertaken with a project to expand the Montecitorio palace in Rome, it is the second school building built in Terni in 1968-69. The Technical Institute for surveyor "Antonio da Sangallo" shows a remarkable compositional coherence that paradoxically derives by a subversion of the compositional and functional order.

Through a process of linguistic contamination, De Feo designs a complex building where he plays with experimentation of serial volumes detectable by outside. 
The building has a longitudinal development and consists of two large elements, a large volume characterized by a continuous inclined plane, which constitutes the main front and ends with an angular semi-pyramid, and a second parallelepiped-shaped factory body, located at the rear where the classrooms are arranged. Between the two volumes there is a road, positioned above a corridor lit by skylight shaped as sliced vault.
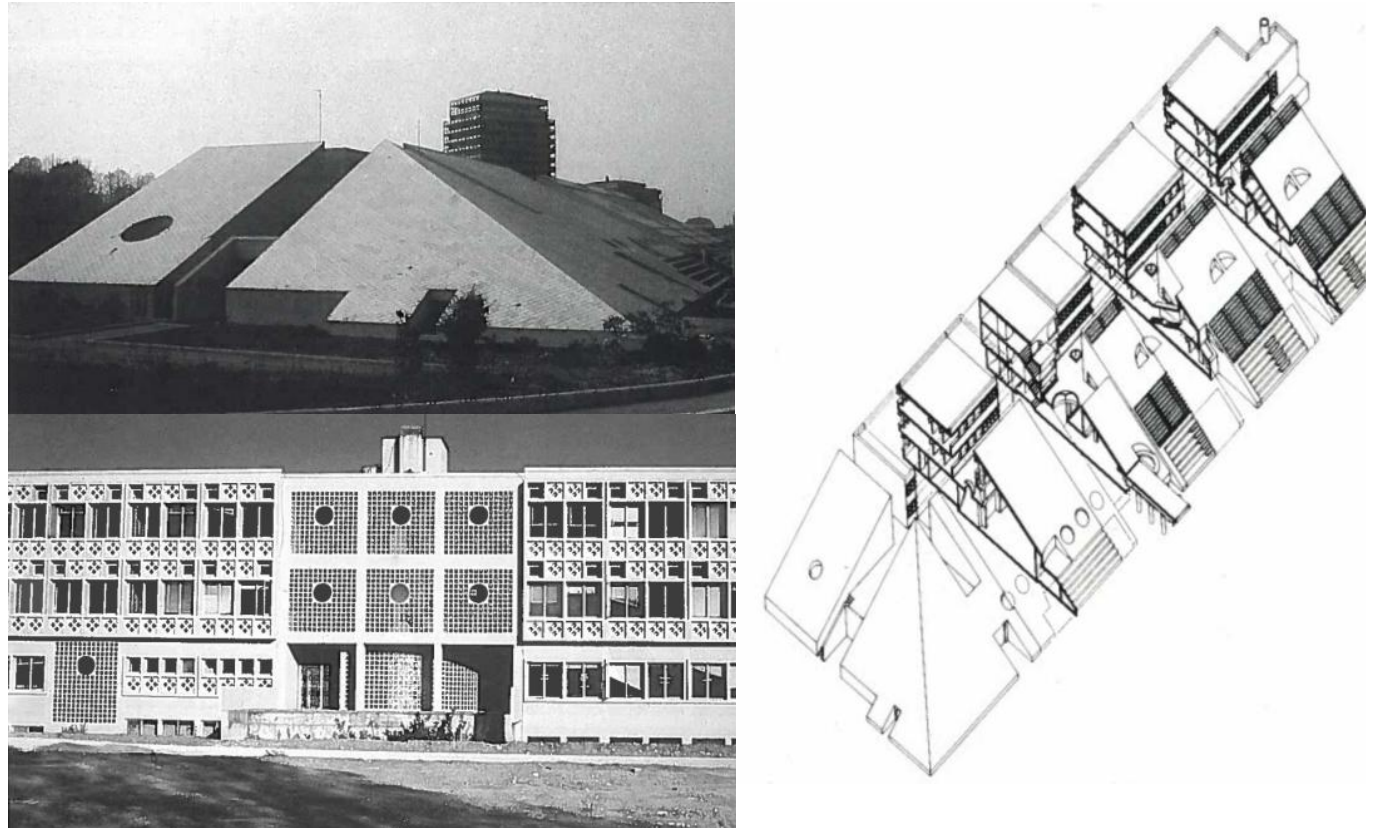

fig. 14-15-16 Views and axonometry of the Technical Institute in Terni

The apparent compactness of the main prospectus actually includes elements linking the life of the building with its surrounding space: in fact, the sloped plane houses the terraces that look out onto the sports fields and a small theatre designed for outdoor events.

The architecture language expresses with the scansions of the façade the differentiation of the interior functions of the building, evident in the intervals between one element and the other. De Feo trusts in geometry and variation of the superficial signs for the modulation of the inclined facade, made more live by the presence of deep cuts and openings of circular or curved shapes.

The classrooms facade, instead, establishes a more explicit dialogue with the surrounding space (city) as it is made of a reinforced concrete grid, interposed in certain sections by concrete glass surfaces. The articulation of this face reveals a certain continuity with Ridolfi's constructive tradition, reworked through a marriage with Perret's teaching. In the architecture panorama of the second half of the 20th century, De Feo set himself as an experimental architect who does not adhere to manifestos or schools of thought, but that works in full intellectual autonomy, interweaving suggestions deduced by the baroque and modern architecture history, that contribute to the formulation of projects in which innovation and tradition contribute to delineating a fragment of city identity. 


\section{The contribution of Viganò in the design of educational spaces}

The constant investigation into the philosophical and technical aspects of making architecture and the attention to the users needs are the elements that lead to a comparison between the works of Vittoriano Viganò, Milanese architect of the "middle generation"(Faroldi\&Vettori, 2004, p.147), and works by Giancarlo De Carlo and Vittorio De Feo.

Viganò's poetry manifests a continuous research for the originality that comes from the tradition: great influences, the Italian Rationalism vicissitudes and in particular the Terragni and Pier Luigi Nervi the works, as well as the influences of the Modern Movement, have exerted. He assimilates the lesson on the use of materials such as beton brit and iron by Le Corbusier and Mies van der Rohe, the flexibility of space and the relationship with the context by Frank Lloyd Wright; the experimentality within the interior design evident in the use of curved plywood by Alvar Aalto.

His direct masters are Giò Ponti and BBPR: in particular, he absorbs interest in interior design, design and color use by Ponti, while admires the intellect and architecture theories of Rogers.

Viganò's career is characterized by architectural culture background of post-war Italy's, in which the ethical and moral commitment required by Reconstruction is accompanied by the desire to formulate an original language.

In the works of Viganò, in particular in the two school buildings that are intended to be here analysed, the theme of architectural space is a fundamental component. As he himself states, the potentialities of shaping space by imagining its future use and the continuity between interior and exterior of the building become substantial elements in its architectures (Viganò, 1975).

In building projects designed to accommodate educational spaces such as the Marchiondi - Spagliardi Institute and the Faculty of Architecture in Milan, Viganò brings together his research in the psychology field, aimed to give ethical and functional answers by the architecture to the users, in this case made up of students of different ages. The goal was to create spaces in which the psychological, theoretical and technological aspects would come together in the design of spaces suitable for the wellness of the learners, to support their process of cultural and moral development.

The Vigano's project of Marchiondi - Spagliardi Institute at Milano-Baggio, realized between 1956 and 1958, attributes to the architect great visibility on the international scene.

Curtis, about Marchiondi Institute, states: "With its strong expression of crude reinforced concrete structure and its clear articulation of functional parts, the building was, in fact, a sculptural descendant of the Italian rationalist genealogy, but in the eyes of British critic Reyner Banham, it was one of the many works in the world that embodied the definite aspirations of his movement, the "New Brutalism"(Curtis, 2006, p.478). 


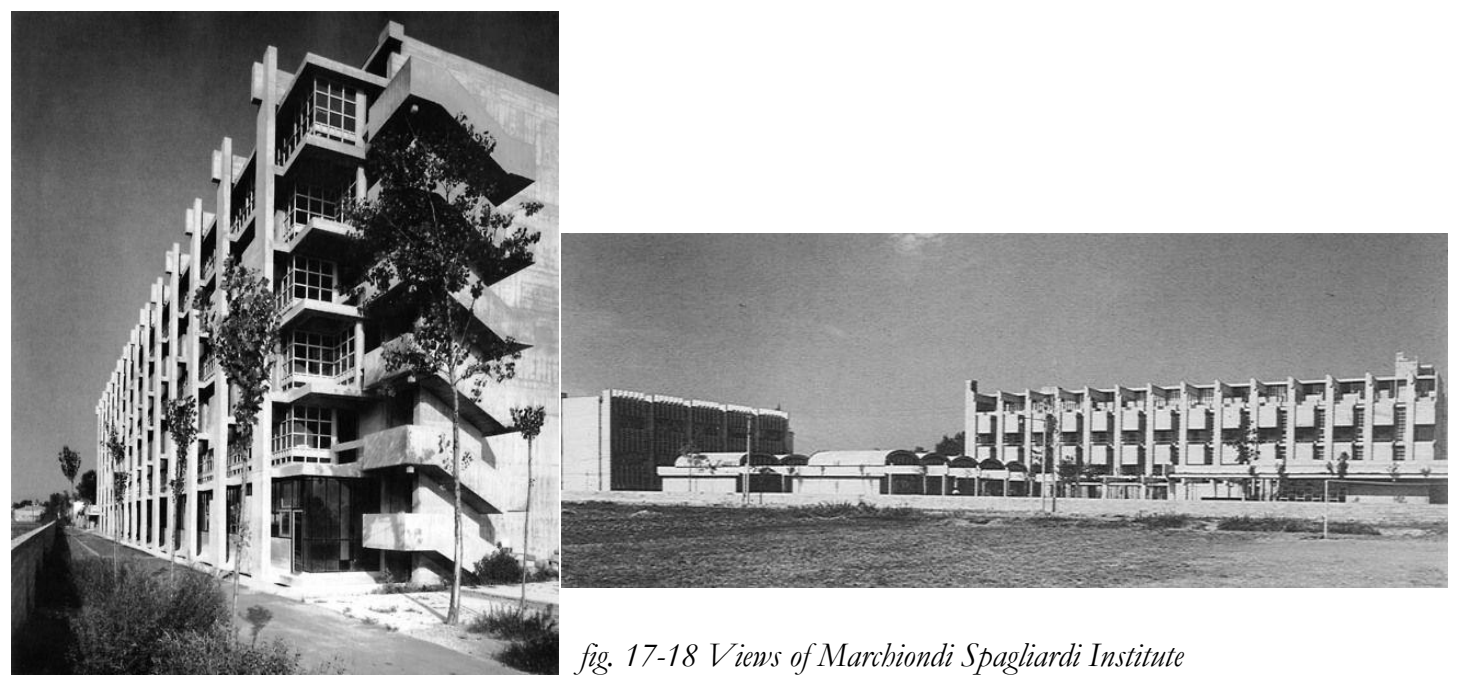

Viganò's contribution to the search for a city identity through the modern language of architecture, takes shape, in this case, in a peripheral context such as the Baggio district. The institute addressed to disadvantaged and abandoned boys, living on the margins of the metropolitan city, wants to give a solid and hospitable answer to the psychological needs of users, which Viganò calls "the best buyers".

The sincerity of the structure dictated by the use of reinforced concrete at sight and the sequence of pillars and open spaces establishes a dialogue with the city, reinforced by the absence of a fence, a particularly innovative choice for such a building in those years.

The complex, associated with international criticism of Smithson and James Stirling works, co-produced in England, stands on a large garden area, on which the various pavilions oriented to an east-west axis overlook.

The structure is articulated in four nuclei that correspond to different functions, linked by covered paths that fit into the surrounding green. They host the boarding schools, the environments for teachers and the school. The rhythmic scan at the top and bottom of the buildings is constant and is characterized by reinforced concrete pillars supporting rectangular cross-sectional beams. Instead, the variation is adopted by the architect in the heights of the buildings and in the interior spaces. By taking the directions of the psychologists and educators, he chooses to abolish the traditional dormitories and to create duplex rooms with a capacity of twelve boys. The toilets are reached going through a glass corridor that enters a walkway.

The continuity between indoor and outdoor space is enhanced by the use of reinforced concrete even in the interior spaces, made flexible by the solution of full-height spaces, livened up by red, white and blue plastered surfaces in the dormitory area.

The possibility to adapt environments to user needs by creating flexible volumes to internal transformations is a constant in Viganò's production.

It is also found in the project to expand the Faculty of Architecture of the Politecnico di Milano, realized between 1974 and 1985. Viganò's intervention connects in a previous project that Giordano Forti, Giò Ponti and Piero Portaluppi implemented only partially. The Viganò project is created around the full height space, where students can relate with great dispositive freedom. The intervention results in a shift of the main entrance to 
Via Ampere, emphasized by the presence of a large red " $\mathrm{A}$ " of Architecture that stands out in the darkness of the pillars (Modena, 2014, p.35).

The Viganò building differs clearly by the pre-existing since it uses steel as an expression to form a new identity of modern architecture in the Milan context.

He assimilates Terragni's teachings about the balanced construction of shape and care detail, and Nervi's teachings about plasticity expressed through materials, but reelaborates them with innovative language and materials.

Constant component in its buildings is the vertical impulse, which in the case of the university building is given by the sequence of vertical elements hanging on large cruciform pillars by means of a tie rods frame set on the top of the pillars themselves. The horizontal elements fit into the vertical ones, allowing the entire structure to enjoy a great spatial fluidity.

Behind the first vertical warp of steel pillars, the building has a glazed tampon at the top, under which there's a large covered patio, a fluid space that connects the road and the city with the university interior life. Here, students study and design freely, disposing of furniture according to their needs.

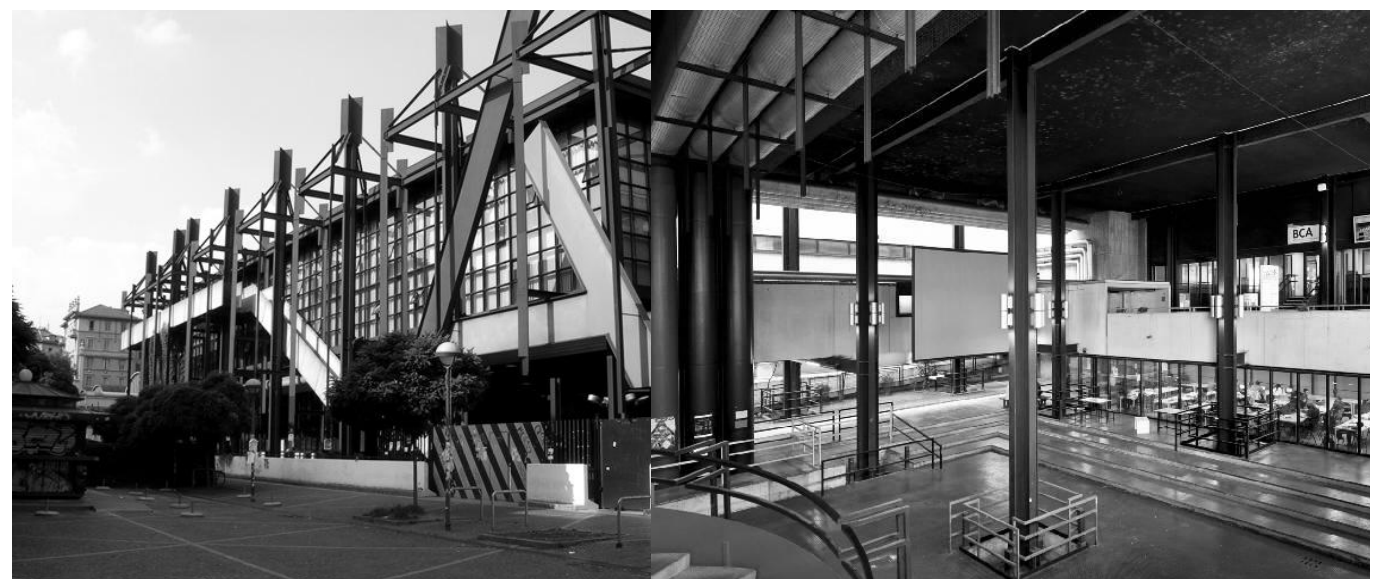

fig. 19-20 Views of Faculty of Architecture in Milan

The space is characterized by the naked display of steel structural elements, by the geometries of suspended crossing gangways, by the scenic presence of the visible plumbing system - highlighted by Viganò with red color- and by the strong plastic value of the helix scale in reinforced concrete which links the entrance level to the one of the underlying patio. A second reinforced concrete staircase runs along the facade on Via Ampère connecting all levels starting by the ground floor and creating a visual and material counterpoint with the structure of painted steel in black and with the glass windows behind; the function of the handrail is here fulfilled by the wall thickness of the parapet (Suriano, 2016).

Though formulating an innovative language that utilizes material technology as a powerful impact tool, the architect constantly seeks to establish a dialogue with preexisting.

The renovated university building is also the place where Viganò spent years for teaching activity with passion, which for him coincided with professional activity. The freedom of 
spaces at full height confers the psychic need of a freedom of thought that fuses tradition and renewal, in which the uniqueness of its architecture comes from a search for continuity with the forms of the place, thus helping to enrich the city of a new identity matrix.

\section{Conclusions}

The architectures identified in this thematic path about the role that educational spaces cover in the urban and territorial spheres, although they are dispersed in time and space, are moments of linguistic, plastic and typological experimentation of remarkable originality, irrespective of the formal outcomes and the ideals of their authors.

The lead that allows to associate the projects of De Carlo, De Feo and Viganò is traceable in the reason of being of these architectures: adapted to the educational and social needs of a specific category of users, open to the surrounding space, integrated in the territorial context and in the city.

In defining the relationship that the spaces of architecture establish with the territory and their power of social renewal, educational structures play a role of primary importance as a place of exchange and connection with the neighborhood and with the city, in which school life and the life of society are called to interfacing with a participation process, which contributes to the conscious development of individuals and the definition of their identity within society.

Acknowledgements: This paper is derived from the author's ongoing $\mathrm{PhD}$ research at the Department of Civil and Building Engineering and Architecture, Università Politecnica delle Marche (UNIVPM, Ancona).

\section{References}

Astengo, G. (1959). Atti del VII convegno nazionale dell'INU. Urbanistica, 39, 7.

Astengo, G. (1962). La nuova dimensione della città. La città-regione. Documents of seminar (19-21 gennaio 1969), ILSES, Milano.

Blundell Jones, P. (2004). Giancarlo De Carlo: opere di "attività professionale. Giancarlo De Carlo - Percorsi, Archivio progetti, I Materiali, IUAV. Padova, Il Poligrafo, 61.

Curtis, W. (2006). L'architettura moderna dal 1900. London, Phaidon Editions, 478.

De Feo, V. (1976). Il piacere dell'architettura. Roma, Magma Editions.

Modena, M. (2014). Villa La scala di Vittoriano Viganò 1956-1958. Degree Thesis, Faculty of Architecture and Society of Mantova, Academic Year 2013/14, 35.

Faroldi, E., \&Vettori, M. P. (2004). Dialoghi di Architettura. Firenze, Alinea,147.

Plummer, H. (2016). L'Esperienza dell'architettura. Torino, Einaudi,152.

Riboldi, S., \& Torricelli, C.(2016). Abitare il coworking. Re-inventare gli spazi del lavoro. BDC 16, 2, Circular Economy and Symbiosis: The Sustainable Regenerative City Model, Università degli Studi di Napoli Federico II, 327.

Rogers, E.N. (1947). Architettura educatrice. Domus - La casa dell'uomo, 220, 1.

Suriano, S. (2016). Facoltà di Architettura del Politecnico di Milano. Record retriewed from http://www.lombardiabeniculturali.it/architetture900/schede/RL560-00057/?offset=4

Tafuri, M. (1986). Storia dell'architettura italiana 1944-1985. Torino, Piccola Biblioteca Einaudi, 98 - 149.

Van Eyck, A. (1966). Il college universitario di Urbino di Giancarlo De Carlo. Zodiac,16.

Viganò, V (1975). Ottagono, 39, december $1975,77$.

Zucchi, B. (1992), Giancarlo De Carlo, Oxford, Butterworth Architecture. 